Papua New Guinea, Samoa, Solomon Islands, Tonga, Tuvalu and Vanuatu. Associate Members. French Polynesia, New Caledonia. Observers. Asian Development Bank, the Commonwealth, TimorLeste, Tokelau, Wallis and Futuna, the World Bank. ${ }^{\star}$ Membership suspended since May 2009 after calls for fresh elections by a set date were ignored.

Functions. The Secretariat's mission is to provide policy options to the Pacific Islands Forum, and to promote Forum decisions and regional and international co-operation. The organization seeks to promote political stability and regional security; enhance the management of economies and the development process; improve trade and investment; and efficiently manage the resources of the Secretariat.

Activities. The Secretariat has four core divisions: Trade and Investment; Political and International Affairs; Development and Economic Policy; Corporate Services. It provides policy advice to members on social, economic and political issues. Since 1989 the Forum has held Post Forum Dialogues with key dialogue partners at ministerial level. There are currently 13 partners: Canada, China, EU, France, India, Indonesia, Italy, Japan, South Korea, Malaysia, the Philippines, the United Kingdom and the United States.

Organization. Established in 1972, the South Pacific Bureau for Economic Co-operation (SPEC) began as a trade bureau before being reorganized as the South Pacific Forum Secretariat in 1988. The Secretariat is headed by a Secretary-General and Deputy Secretary-General who form the Executive. The governing body is the Forum Officials Committee, which acts as an intermediary between the Secretariat and the Forum. The Secretariat operates four Trade Offices in Auckland, Beijing, Sydney and Tokyo.

The Secretary-General is the permanent Chair of the Council of Regional Organisations in the Pacific (CROP), which brings together ten main regional organizations in the Pacific region: Fiji School of Medicine (FSM); Forum Fisheries Agency (FFA); Pacific Islands Development Programme (PIDP); Pacific Islands Forum Secretariat (PIFS); Secretariat for the Pacific Community (SPC); South Pacific Applied Geoscience Commission (SOPAC); South Pacific Board for Educational Assessment (SPBEA); South Pacific Regional Environment Programme (SPREP); South Pacific Tourism Organisation (SPTO); and the University of the South Pacific (USP).

Official language: English.

Headquarters: Ratu Sukuna Road, Suva, Fiji Islands.

Website: http://www.forumsec.org.fj

Secretary-General: Tuiloma Neroni Slade (Samoa).

\section{Secretariat of the Pacific Community (SPC)}

Until Feb. 1998 known as the South Pacific Commission, this is a regional intergovernmental organization founded in 1947 under an Agreement commonly referred to as the Canberra Agreement. It is funded by assessed contributions from its 26 members and by voluntary contributions from member and non-member countries, international organizations and other sources.

Members. American Samoa, Australia, Cook Islands, Fiji Islands, France, French Polynesia, Guam, Kiribati, Marshall Islands, Federated States of Micronesia, Nauru, New Caledonia, New Zealand, Niue, Northern Mariana Islands, Palau, Papua New Guinea, Pitcairn Islands, Samoa, Solomon Islands, Tokelau, Tonga, Tuvalu, USA, Vanuatu, and Wallis and Futuna.
Functions. The SPC has three main areas of work: land resources, marine resources and social resources. It conducts research and provides technical assistance and training in these areas to member Pacific Island countries and territories of the Pacific.

Organization. The Conference of the Pacific Community is the governing body of the Community. Its key focus is to appoint the Director-General, to consider major national or regional policy issues and to note changes to the Financial and Staff Regulations approved by the CRGA, the Committee of Representatives of Governments and Administrations. It meets every two years. The CRGA meets once a year and is the principal decision-making organ of the Community. There are also regional offices in the Fiji Islands and Micronesia.

Headquarters: BP D5, 98848 Nouméa Cedex, New Caledonia.

Website: http://www.spc.int

Email: spc@spc.int

Director-General: Dr Jimmie Rodgers (Solomon Islands).

\section{South Asian Association for Regional Co-operation (SAARC)}

SAARC was established to accelerate the process of economic and social development in member states. The foreign ministers of the seven member countries met for the first time in New Delhi in Aug. 1983 and adopted the Declaration on South Asian Regional Co-operation whereby an Integrated Programme of Action (IPA) was launched. The charter establishing SAARC was adopted at the first summit meeting in Dhaka in Dec. 1985.

Members. Afghanistan, Bangladesh, Bhutan, India, Maldives, Nepal, Pakistan, Sri Lanka. Observers. Australia, China, EU, Iran, Japan, South Korea, Mauritius, Myanmar, USA.

Objectives. To promote the welfare of the peoples of South Asia; to accelerate economic growth, social progress and cultural development; to promote and strengthen collective self-reliance among members; to promote active collaboration and mutual assistance in the economic, social, cultural, technical and scientific fields; to strengthen co-operation with other developing countries and among themselves. Co-operation within the framework is based on respect for the principles of sovereign equality, territorial integrity, political independence, non-interference in the internal affairs of other states and mutual benefit. Agreed areas of co-operation under the Integrated Programme of Action (IPA) include agriculture and rural development; human resource development; environment, meteorology and forestry; science and technology; transport and communications; energy; and social development.

A SAARC Preferential Trading Arrangement (SAPTA) designed to reduce trade tariffs between SAARC member states was signed in April 1993, entering into force in Dec. 1995. In 1998 at the Tenth Summit in Colombo, the importance of achieving a South Asian Free Trade Area (SAFTA) as mandated by the Malé Summit in 1997 was reiterated and it was decided to set up a Committee of Experts to work on drafting a comprehensive treaty regime for creating a free trade area. The Colombo Summit agreed that the text of this regulatory framework would be finalized by 2001 .

Organization. The highest authority of the Association rests with the heads of state or government, who meet annually at Summit level. The Council of Foreign Ministers, which meets twice a year, formulates policy, reviews progress and decides on new areas of co-operation. The Council is supported by a Standing Committee of Foreign Secretaries, by the Programming Committee and by 11 Technical Committees which are responsible for individual areas of SAARC's activities. There is a secretariat in Kathmandu, 